\title{
Effects of supplementing Holstein cows with soybean oil compared with palmitic acid-enriched triglycerides on milk production and nutrient partitioning
}

\author{
E. Liu, $\odot$ M. J. VandeHaar, $\odot$ and A. L. Lock* ${ }^{*}$ \\ Department of Animal Science, Michigan State University, East Lansing 48824
}

\begin{abstract}
Both insulin and trans-10,cis-12 C18:2 (t10c12CLA) can be increased by high-starch diets; thus, it is difficult to determine whether insulin or t10c12CLA mediates nutrient partitioning toward body tissues during milk fat depression. To minimize insulin secretion while manipulating t10c12CLA levels, diets supplemented with palmitic acid-enriched triglycerides and soybean oil were fed to cows. Thirty-two Holstein cows (93 \pm $35 \mathrm{~d}$ in milk) were included in the crossover experiment with each treatment period being $28 \mathrm{~d}$. Treatment diets contained 25\% neutral detergent fiber, $32 \%$ starch, $18 \%$ crude protein, and $4.6 \%$ fatty acids (dry matter basis). Treatment diets contained either palmitic acid-enriched triglycerides (2.5\% dry matter, BergaFat T-300, Berg + Schmidt America LLC, Libertyville, IL; PAT) or soybean oil (2.5\% dry matter; SBO). Cows were blocked by milk yield, body weight, and parity, and then randomly assigned to 1 of 2 treatment sequences (PAT-SBO or SBO-PAT). Cows fed PAT produced milk with only $3.1 \%$ fat, indicating milk fat depression; SBO decreased fat content further to only $2.4 \%$. No effect of treatment was observed on dry matter intake, apparent net energy intake, milk yield, body condition score, or fat thickness over the rump and rib. However, compared with PAT, SBO decreased fat-corrected milk yield, energy-corrected milk yield, milk fat yield, de novo fatty acids, and 16-carbon fatty acid yield, whereas SBO increased body weight gain. Neutral detergent fiber digestibility tended to be lower in SBO, whereas fatty acid digestibility was higher. Additionally, the concentration of plasma insulin, nonesterified fatty acids, and triglycerides, and milk metabolites (trans-10 C18:1 and t10c12CLA) were all higher in SBO. In conclusion, with similar dietary starch content, the diet containing palmitic acid-enriched triglycerides
\end{abstract}

Received December 20, 2019.

Accepted April 26, 2020.

*Corresponding author: allock@msu.edu partitioned more energy toward milk synthesis, whereas the diet containing soybean oil partitioned more energy toward body tissue gain.

Key words: milk fat depression, insulin, trans-10,cis-12 conjugated linoleic acid

\section{INTRODUCTION}

In cows suffering milk fat depression (MFD), more nutrients are stored in adipose tissues, whereas fewer are used for milk fat synthesis (Van Soest, 1963; Bauman and Griinari, 2001; Boerman et al., 2015). Insulin and CLA have been well recognized as key mediators in nutrient partitioning during lactation. The role of plasma insulin in nutrient partitioning is well established (Bauman and Griinari, 2001). Ruminal CLA isomers have also been documented as key regulators in nutrient partitioning during MFD. Plasma insulin prevents lipolysis and stimulates lipid synthesis in adipose tissues (Vernon, 2005; Bauman et al., 2011), and decreases fatty acid (FA) availability for milk fat synthesis (McClymont and Vallance, 1962); therefore, insulin favors energy partitioning toward body tissue gain instead of milk synthesis. Specific CLA isomers, especially trans-10,cis-12 C18:2 (t10c12CLA), are known as potent inhibitors of milk fat synthesis (Bauman et al., 2011). Harvatine et al. (2009) reported that milk energy output decreased the expression of lipogenic genes in adipose tissue increased in cows suffering CLA-induced MFD. Thus, t10c12CLA also favors energy flow toward body tissue gain instead of milk synthesis. Both t10c12CLA and insulin are potent regulators of energy partitioning in lactating dairy cows; however, to our knowledge, no studies have tried to separate the effect of these.

In Boerman et al. (2015), cows fed a high-starch diet exhibited MFD and significant body tissue gain, along with higher concentrations of plasma insulin and milk trans-10 C18:1 (a robust marker of alterations in ruminal biohydrogenation and inhabitation of milk fat synthesis; Bauman et al., 2011). As high-starch diets 
were fed to cows to induce MFD in Boerman et al. (2015), both insulin and t10c12CLA were increased in that study, and thus we were not able to separate the effects of insulin and t10c12CLA. Both mechanisms may have caused the diet-induced MFD and increased BW gain. Whether it was insulin, t10c12CLA, or both that altered nutrient partitioning was not clear. One way to better understand the effect of t10c12CLA on nutrient partitioning is to increase t10c12CLA production while minimizing insulin secretion. To do this, we fed cows 2 isoenergetic and isolipid diets with similar starch content but supplemented with either palmitic acid-enriched triglycerides or soybean oil. With these 2 supplements, we could cause MFD with the diet containing soybean oil while minimizing rumen issues and promoting milk fat synthesis with the diet containing palmitic acid-enriched triglycerides. We hypothesized that feeding mid-lactation cows a diet containing soybean oil would enhance ruminal CLA production, cause almost no change in insulin concentration, and partition more energy toward body tissue.

\section{MATERIALS AND METHODS}

\section{Cows, Experimental Design, and Diets}

Experimental procedures were approved by the Institutional Animal Care and Use Committee of Michigan State University. Thirty-two mid-lactation Holstein cows (14 primiparous and 18 multiparous) were included in a crossover design experiment with two 28-d treatment periods. Cows were blocked by milk yield, parity, and BW, and randomly assigned to one of the treatment sequences. Mean DIM, BW, and milk yield were $93 \pm 35 \mathrm{~d}, 668 \pm 61 \mathrm{~kg}$, and $46 \pm 11 \mathrm{~kg} / \mathrm{d}$ (mean $\pm \mathrm{SD}$ ) at the start of the experiment, respectively. Cows were housed in individual tiestalls and milked twice daily. Water was available ad libitum. Feed was offered once daily at $1200 \mathrm{~h}$ at $115 \%$ of expected intake.

Treatment diets were supplemented with either palmitic acid-enriched triglycerides $[2.5 \%$ DM, BergaFat T-300 (Berg + Schmidt America LLC, Libertyville, IL); PAT] or soybean oil (2.5\% DM; SBO; Table 1). Forages were corn silage and alfalfa silage. Mineral and vitamins were formulated according to NRC (2001). The feed ingredients and nutrient composition of the TMR diets are described in Table 1. Diets were adjusted for changes in forage DM concentration twice weekly when necessary.

\section{Sample Collection and Analysis}

Milk yield was recorded daily and milk samples at each milking were collected for 2 consecutive days each week throughout the study for the calculation of energy partitioning. Data and samples for production performance, digestibility, and plasma metabolites/ hormones were intensively collected during the final 5 d of each treatment period. Samples of 10 consecutive milkings were collected from individual cows. Two aliquots of the milk samples from each cow were collected at each milking. One of the aliquots was analyzed for fat, protein, and lactose using infrared spectroscopy by Michigan DHIA (Grand Ledge, MI). The other aliquot was stored at $-20^{\circ} \mathrm{C}$; the 10 samples were subsequently composited based on milk fat yield (d 24-28 of each

Table 1. Ingredients and nutrient composition of treatment $\operatorname{diets}^{1,2,3}$

\begin{tabular}{lcc}
\hline & \multicolumn{2}{c}{ Treatment } \\
\cline { 2 - 3 } Item & PAT & SBO \\
\hline Ingredient, \% of DM & & \\
Corn silage & 29.0 & 29.1 \\
Alfalfa silage & 14.1 & 14.1 \\
Cottonseed, whole & 5.3 & 5.3 \\
Corn, ground & 10.5 & 10.5 \\
Corn, high moisture & 18.5 & 18.5 \\
Soybean meal & 16.7 & 16.7 \\
C16:0-enriched fat supplement ${ }^{4}$ & 2.5 & - \\
Soybean oil & - & 2.5 \\
Vitamin and mineral premix ${ }^{5}$ & 2.0 & 2.0 \\
Limestone & 0.7 & 0.7 \\
Sodium bicarbonate & 0.7 & 0.7 \\
Forage:concentrate & $43: 57$ & $43: 57$ \\
Nutrient composition, \% of DM & & \\
DM ${ }^{6}$ & 57.1 & 57.1 \\
NDF & 25.0 & 25.1 \\
Forage NDF & 18.1 & 18.2 \\
CP & 18.2 & 17.9 \\
Starch & 31.6 & 31.9 \\
Fatty acids & 4.79 & 4.40 \\
16-Carbon fatty acids & 2.19 & 0.64 \\
18-Carbon fatty acids & 2.48 & 3.65 \\
Apparent NE ${ }^{7}$ Mcal/kg & 1.64 & 1.66 \\
\hline
\end{tabular}

${ }^{1}$ Experimental diets fed to 32 cows in a crossover design within 28-d periods.

${ }^{2}$ Treatments contained $2.5 \%$ added palmitic acid-enriched triglyceride (PAT) or soybean oil (SBO) on a DM basis.

${ }^{3}$ Nutrient composition was determined from feed ingredients sampled during the last $5 \mathrm{~d}$ of each 28-d experimental period.

${ }^{4}$ BergaFat T-300 (Berg + Schmidt America LLC, Libertyville, IL).

${ }^{5}$ The vitamin and mineral premix was designed to meet the mineral and vitamin requirements of lactating cows as set forth by NRC (2001). The premix mix contained $34.1 \%$ dry ground shelled corn, $25.6 \%$ white salt, $21.8 \%$ calcium carbonate, $9.1 \%$ Biofos (Mosaic, Tampa, FL), $3.9 \%$ magnesium oxide, $2 \%$ soybean oil, and $<1 \%$ of each of the following: manganese sulfate, zinc sulfate, ferrous sulfate, copper sulfate, iodine, cobalt carbonate, vitamin E, vitamin A, vitamin $\mathrm{D}$, and selenium.

${ }^{6} \mathrm{DM}$ was expressed as a percentage of as fed.

${ }^{7}$ Mean apparent net energy concentration of diets, based on average cow performance. For each diet, diet $\mathrm{NE}_{\mathrm{L}}=$ the average of (MilkE + $0.08 \times \mathrm{MBW}+\Delta$ BodyE) $/ \mathrm{DMI}$ for all cows on the diet, where MilkE is net energy used for milk synthesis, MBW is metabolic body weight $\left(\mathrm{BW}^{0.75}\right)$, and $\triangle$ BodyE is net energy captured in body tissue. 
period). Milk lipids were extracted, and FAME were prepared using sodium methoxide solution in methanol and quantified using GLC according to our methods described previously (Lock et al., 2013). Individual FAME were identified by comparison of retention times with known FAME standards. Yield of individual FA (g/d) in milk fat were calculated by using milk fat yield and FA concentration to determine yield on a mass basis using the molecular weight of each FA while correcting for glycerol content and other milk lipid classes (Piantoni et al., 2013).

Cows were weighed 3 times per week immediately following afternoon milkings throughout the study. Body condition score for each cow, calculated as the average score of 3 trained investigators, was recorded on a 5-point scale at the end of each period. On the last day of each period, subcutaneous fat thickness was measured at the 12th intercostal space for rib fat and the sacral region between the tuber coxae (hooks) and tuber ischia (pins) for rump fat via ultrasound scanning. The National Centralized Ultrasound Processing Lab (Ames, IA) analyzed the ultrasound images, and the change in subcutaneous fat thickness was calculated as the difference between consecutive measurements.

During the last $5 \mathrm{~d}$ of each experimental period, samples of feed ingredients $(\sim 0.5 \mathrm{~kg})$ and orts $(12.5 \%)$ for individual cows were collected daily and composited for each cow by period. Samples of feces were collected every $15 \mathrm{~h}$ to provide 8 samples per cow during the last $5 \mathrm{~d}$ of each period $(1200,0300,1800,0900,2400,1500$, 0600, and $2100 \mathrm{~h}$ ). Fecal samples were stored at $-20^{\circ} \mathrm{C}$ after collection until being dried. Samples of feed ingredients, orts, and feces were dried using a forced-air oven $\left(55^{\circ} \mathrm{C}\right.$ for $\left.72 \mathrm{~h}\right)$ before being ground through a Wiley mill (2-mm screen for cottonseed, 1-mm screen for other ingredients, orts, and fecal sample; Arthur H. Thomas Co., Philadelphia, PA). Following grinding, individual fecal samples were composited for each cow by period, on an equal DM basis.

Feed ingredients, orts, and feces were analyzed for NDF, indigestible NDF, and FA. The NDF and indigestible NDF were measured using methods described by Mertens (2002) and Goering and Van Soest (1970), respectively. Indigestible NDF was used as an internal marker to estimate fecal output and nutrient digestibility (Cochran et al., 1986). The concentration of FA in feed ingredients, orts, and feces were determined as described by Lock et al. (2013). Additionally, feed ingredients were analyzed for $\mathrm{CP}$ and starch (AOAC, 1990) by Cumberland Valley Analytical Services Inc. (Hagerstown, MD).

Blood was sampled at the same time as fecal collection, via coccygeal venipuncture into three 6 -mL evacuated tubes. Two tubes contained potassium EDTA and the third one contained potassium oxalate with sodium fluoride as glycolytic inhibitors. Immediately after collection, plasma was separated from red blood cells by centrifugation at $2,000 \times g$ for $15 \mathrm{~min}$ at $4^{\circ} \mathrm{C}$ and then stored at $-20^{\circ} \mathrm{C}$ until composited into one sample per cow per period. Commercial kits were used to determine plasma concentration of nonesterified fatty acids [NEFA-HR (2) kit, Wako Chemicals, Richmond, VA], insulin (Bovine Insulin ELISA, Mercodia, Uppsala, Sweden), and triglycerides (L-Type triglyceride M kit, Wako Chemicals). Plasma glucose concentration was determined by a glucose oxidase method (PGO Enzyme Product No. P7119, Sigma Chemical Co.).

\section{Calculations}

Weekly milk yields of fat, protein, and lactose obtained from 4 consecutive milkings, weekly BW, and period BCS were included in the energy partitioning calculations. Milk energy output, metabolic BW, and body tissue gain throughout treatment periods were calculated based on the data above.

Milk energy output (MilkE; Mcal/d) for each cow was estimated by the following equation (NRC, 2001; from Equation 2-15):

$$
\begin{aligned}
\text { MilkE }=9.29 & \times \text { fat }(\mathrm{kg})+5.63 \times \text { true protein }(\mathrm{kg}) \\
& +3.95 \times \text { lactose }(\mathrm{kg}),
\end{aligned}
$$

where each component was the average output of each cow during the 28-d period. Metabolic BW (MBW; $\mathrm{kg}^{0.75}$ ) was estimated as $\mathrm{BW}^{0.75}$, where $\mathrm{BW}$ was the mean BW of each cow during the 28-d period.

Energy for maintenance (MaintE; Mcal/d) for each cow was estimated as

$$
\text { MaintE }=0.08 \times \mathrm{MBW} .
$$

Mean daily $\mathrm{BW}$ change $(\Delta \mathrm{BW} ; \mathrm{kg} / \mathrm{d})$ was calculated for each cow within the treatment period by linear regression after 2 rounds of removing outliers in the data; an outlier was any $\mathrm{BW}>3.5 \mathrm{SD}$ from the regression line.

Energy expended for body tissue gain ( $\Delta$ BodyE; $\mathrm{Mcal} / \mathrm{d}$ ) was estimated by an equation derived from NRC (2001; Table 2, 3, 4, and 5):

$$
\Delta \mathrm{BodyE}=(2.88+1.036 \times \mathrm{BCS}) \times \Delta \mathrm{BW},
$$

where BCS was the average BCS for each cow during the 28-d period.

Energy partitioning was predicted based on observed performance: 
Table 2. Dry matter intake, milk production, milk components, and feed efficiency for cows fed treatment diets $(\mathrm{n}=32)$

\begin{tabular}{|c|c|c|c|c|}
\hline \multirow[b]{2}{*}{ Item } & \multicolumn{2}{|c|}{ Treatment $^{1}$} & \multirow[b]{2}{*}{ SEM } & \multirow{2}{*}{$\frac{P \text {-value }}{2,3}$} \\
\hline & PAT & SBO & & \\
\hline DMI & 25.0 & 24.9 & 0.63 & 0.65 \\
\hline \multicolumn{5}{|l|}{ Milk yield, $\mathrm{kg} / \mathrm{d}$} \\
\hline Milk & 46.1 & 46.5 & 1.75 & 0.58 \\
\hline $\mathrm{ECM}^{4}$ & 42.6 & 39.8 & 1.56 & $<0.01$ \\
\hline $3.5 \% \mathrm{FCM}^{5}$ & 41.9 & 38.1 & 1.60 & $<0.01$ \\
\hline \multicolumn{5}{|l|}{ Milk component } \\
\hline Fat, kg/d & 1.35 & 1.11 & 0.05 & $<0.01$ \\
\hline Fat, $\%$ & 3.07 & 2.42 & 0.13 & $<0.01$ \\
\hline Protein, $\mathrm{kg} / \mathrm{d}$ & 1.40 & 1.44 & 0.05 & 0.04 \\
\hline Protein, \% & 3.05 & 3.12 & 0.03 & $<0.01$ \\
\hline Lactose, $\mathrm{kg} / \mathrm{d}$ & 2.21 & 2.24 & 0.08 & 0.42 \\
\hline Lactose, \% & 4.81 & 4.83 & 0.03 & 0.2 \\
\hline $\mathrm{ECM} / \mathrm{DMI}^{6}$ & 1.67 & 1.53 & 0.04 & $<0.01$ \\
\hline
\end{tabular}

${ }^{1}$ Treatments contained $2.5 \%$ added palmitic acid-enriched triglyceride (PAT) or $2.5 \%$ soybean oil (SBO) on a DM basis.

${ }^{2} P$-value associated with treatment differences (PAT vs. SBO; TRT).

${ }^{3}$ All $P$-values for period $\times$ treatment were greater than 0.60 .

${ }^{4} \mathrm{ECM}=[(0.327 \times \mathrm{kg}$ of milk $)+(12.95 \times \mathrm{kg}$ of milk fat $)+(7.20 \times$ $\mathrm{kg}$ of milk protein)] (Tyrrell and Reid, 1965).

${ }^{5} 3.5 \% \mathrm{FCM}=[(0.4324 \times \mathrm{kg}$ of milk $)+(16.216 \times \mathrm{kg}$ of milk fat $)]$.

${ }^{6}$ Milk:feed ratio $=\mathrm{ECM} / \mathrm{DMI}$.
$\%$ milk, maintenance, or body tissue $=$

MilkE, MaintE, or BodyE/

$($ MilkE + MaintE $+\Delta$ BodyE $) \times 100$,

where $\%$ to milk, maintenance, or body tissue was the percentage of apparent net energy partitioned to milk production, maintenance requirement, or body tissue gain, respectively.

Milk to feed ratio for each cow per period was calculated as the average daily ECM yield over the average daily DMI, where $\mathrm{ECM}=0.327 \times$ milk $(\mathrm{kg})+12.95 \times$ fat $(\mathrm{kg})+7.20 \times$ protein $(\mathrm{kg})$ (Tyrrell and Reid, 1965).

Apparent diet energy content $\left(\operatorname{DietNE}_{\mathrm{L}} ; \mathrm{Mcal} / \mathrm{kg}\right)$ for each cow on each diet was calculated as the average $\mathrm{NE}_{\mathrm{L}}$ divided by the average daily DMI:

$$
\operatorname{DietNE}_{\mathrm{L}}=(\text { MilkE }+ \text { MaintE }+\Delta \text { BodyE }) / \text { DMI }
$$

\section{Statistical Analysis}

Treatment responses for production performance, production efficiency, FA profile, blood metabolites/ hormones, and digestibility were analyzed using the Mixed procedure in SAS (version 9.4, SAS Institute

Table 3. Body weight, BCS, and change in subcutaneous fat thickness measurements and calculated energy values for cows fed treatment diets $(\mathrm{n}=32)$

\begin{tabular}{|c|c|c|c|c|}
\hline \multirow[b]{2}{*}{ Variable } & \multicolumn{2}{|c|}{ Treatment $^{1}$} & \multirow[b]{2}{*}{ SEM } & \multirow{2}{*}{$\frac{P \text {-value }}{2,3}$} \\
\hline & PAT & SBO & & \\
\hline $\mathrm{BW}$ & 677 & 681 & 10.9 & 0.09 \\
\hline $\mathrm{BCS}$ & 3.29 & 3.33 & 0.07 & 0.13 \\
\hline Change in $\mathrm{BW},{ }^{4} \mathrm{~kg} / \mathrm{d}$ & 0.19 & 0.46 & 2.37 & 0.04 \\
\hline Change in BCS, point $/ 28 \mathrm{~d}$ & 0.11 & 0.12 & 0.03 & 0.81 \\
\hline Change in rump fat, $\mathrm{mm} / 28 \mathrm{~d}$ & 0.20 & 0.06 & 0.19 & 0.67 \\
\hline Change in rib fat, $\mathrm{mm} / 28 \mathrm{~d}$ & 0.33 & 0.57 & 0.18 & 0.45 \\
\hline \multicolumn{5}{|l|}{ Calculated energy value ${ }^{5}$} \\
\hline Apparent $\mathrm{NE}_{\mathrm{L}}$ of diet, $\mathrm{Mcal} / \mathrm{kg}$ & 1.64 & 1.66 & 0.03 & 0.51 \\
\hline Milk, Mcal/d & 29.1 & 27.1 & 1.12 & $<0.01$ \\
\hline Body tissue gain, Mcal/d & 1.40 & 3.33 & 0.55 & $<0.01$ \\
\hline Maintenance, Mcal/d & 10.6 & 10.7 & 0.13 & 0.17 \\
\hline \multicolumn{5}{|l|}{ Partitioning ${ }^{6}$} \\
\hline Milk, \% & 70.8 & 65.8 & 1.4 & $<0.01$ \\
\hline Body tissue gain, $\%$ & 3.4 & 8.1 & 1.5 & $<0.01$ \\
\hline Maintenance, \% & 25.7 & 26.0 & 0.6 & 0.79 \\
\hline
\end{tabular}

${ }^{1}$ Treatments contained $2.5 \%$ added palmitic acid-enriched triglyceride (PAT) or 2.5\% soybean oil (SBO) on a DM basis.

${ }^{2} P$-value associated with treatment differences (PAT vs. SBO; TRT).

${ }^{3}$ All $P$-value for period $\times$ treatment are over 0.50 .

${ }^{4}$ Determined by linear regression using BW measurements throughout the period.

${ }^{5}$ Milk $($ MilkE $)=[9.29 \times$ fat $(\mathrm{kg})+5.63 \times$ true protein $(\mathrm{kg})+3.95 \times$ lactose $(\mathrm{kg})]$. Body tissue gain $(\Delta$ BodyE $)$ $=[(2.88+1.036 \times \mathrm{BCS}) \times \Delta \mathrm{BW}]$, maintenance $=0.08 \times \mathrm{MBW}$.

${ }^{6 \%}$ to milk, maintenance, or body tissue $=[$ MilkE, $0.08 \times$ MBW, or $\Delta$ BodyE $/($ MilkE $+0.08 \times \mathrm{MBW}+$ $\triangle$ BodyE $) \times 100$ ], where MilkE is net energy used for milk synthesis, MBW is metabolic body weight, and $\Delta$ BodyE is net energy captured in body tissue. 
Table 4. Nutrient intake and nutrient digestibility for cows fed treatment diets $(\mathrm{n}=32)$

\begin{tabular}{lrrrrr}
\hline & \multicolumn{2}{c}{ Treatment $^{1}$} & & & $P$-value \\
\cline { 2 - 3 } \cline { 5 - 5 } Nutrient & PAT & SBO & & SEM & TRT \\
\hline Intake, g/d & & & & \\
Total FA & 1,218 & 1,110 & 29.8 & $<0.01$ \\
16 Carbon & 548 & 159 & 8.53 & $<0.01$ \\
18 Carbon & 620 & 909 & 13.0 & $<0.01$ \\
Digestibility, $\%$ & & & & \\
DM & 64.9 & 64.2 & 0.55 & 0.34 \\
NDF & 29.1 & 26.4 & 1.47 & 0.09 \\
Total FA & 62.2 & 68.1 & 1.26 & $<0.01$ \\
16 Carbon & 52.4 & 68.5 & 1.51 & $<0.01$ \\
18 Carbon & 72.9 & 69.9 & 1.34 & 0.04 \\
Absorbed, g/d & & & & \\
Total FA & 759 & 756 & 16.2 & 0.32 \\
16 Carbon & 287 & 109 & 6.30 & $<0.01$ \\
18 Carbon & 452 & 635 & 9.32 & $<0.01$ \\
\hline
\end{tabular}

${ }^{1}$ Treatments contained $2.5 \%$ added palmitic acid-enriched triglyceride (PAT) or $2.5 \%$ soybean oil (SBO) on a DM basis.

${ }^{2} P$-value associated with treatment differences (PAT vs. SBO; TRT).

${ }^{3}$ All $P$-value for period $\times$ treatment are over 0.15 , except for total fatty acids $(\mathrm{FA} ; P=0.04)$ and 18 -carbon $\mathrm{FA}(P=0.04)$. In period 1 , total FA digestibility was higher in SBO (68. $1 \%$ vs. $57.4 \%, P<0.01)$, whereas in period 2, total FA digestibility was similar between SBO and PAT ( $68.7 \%$ vs. $66.9 \%, P=0.48)$. In period $1, \mathrm{C} 18 \mathrm{FA}$ digestibility was similar between SBO and PAT (67.3\% vs. $69.1 \%, P=0.51$ ), whereas in period 2, C18 FA digestibility was lower in SBO (78.6\% vs. $70.7 \%, P<0.01)$.

Inc., Cary, NC) according to the model $\mathrm{Y}_{\mathrm{ijk}}=\mu+\mathrm{T}_{\mathrm{i}}+$ $\mathrm{P}_{\mathrm{j}}+\mathrm{T}_{\mathrm{i}} \times \mathrm{P}_{\mathrm{j}}+\mathrm{C}_{\mathrm{k}}+\mathrm{e}_{\mathrm{ijk}}$, where $\mathrm{Y}_{\mathrm{ijk}}$ was the dependent variable, $\mu$ was the overall mean, $T_{i}$ was the fixed effect of treatment ( $\mathrm{i}=\mathrm{PAT}$ or $\mathrm{SBO}), \mathrm{P}_{\mathrm{j}}$ was the fixed effect of period $(\mathrm{j}=1$ or 2$), \mathrm{T}_{\mathrm{i}} \times \mathrm{P}_{\mathrm{j}}$ was the interaction between treatment and period, $\mathrm{C}_{\mathrm{k}}$ was the random effect of cow $(\mathrm{k}=1, \ldots, 32)$, and $\mathrm{e}_{\mathrm{ijk}}$ was the residual error.

Main effects were considered significant at $P<0.05$ and trends at $P<0.10$. Interactions were considered significant at $P \leq 0.10$ and trends at $P \leq 0.15$. All

Table 5. Plasma concentrations of glucose, insulin, nonesterified fatty acids (NEFA), and triglycerides (TAG) for cows fed treatment diets $(\mathrm{n}=32)$

\begin{tabular}{|c|c|c|c|c|}
\hline \multirow[b]{2}{*}{ Variable } & \multicolumn{2}{|c|}{ Treatment $^{1}$} & \multirow[b]{2}{*}{ SEM } & \multirow{2}{*}{$\frac{P \text {-value }}{2,3}$} \\
\hline & PAT & SBO & & \\
\hline Glucose, mg/dL & 59.6 & 60.1 & 0.42 & 0.25 \\
\hline Insulin, $\mu \mathrm{g} / \mathrm{L}$ & 1.18 & 1.34 & 0.05 & 0.03 \\
\hline NEFA, $\mu \mathrm{Eq} / \mathrm{L}$ & 122 & 137 & 5.3 & $<0.01$ \\
\hline TAG, mg/dL & 7.9 & 8.5 & 0.29 & 0.05 \\
\hline
\end{tabular}

${ }^{1}$ Treatments contained $2.5 \%$ added palmitic acid-enriched triglyceride (PAT) or soybean oil (SBO) on a DM basis.

${ }^{2} P$-value associated with treatment differences (PAT vs. SBO; TRT).

${ }^{3}$ All $P$-values for treatment $\times$ period are over 0.70 except for glucose $(P=0.06)$. In period 1 , plasma glucose concentration was lower in SBO (59.0 vs. $61.4, P=0.04$ ); in period 2, plasma glucose concentration was similar between SBO and PAT (60.2 vs. $58.9, P=0.04)$. results were expressed as least squares means and standard error of means in the tables unless otherwise specified.

\section{RESULTS}

\section{Production Performance}

Treatment did not alter milk yield $(P=0.58)$ or DMI $(P=0.65$; Table 2$)$. Compared with PAT, SBO decreased FCM by $3.8 \mathrm{~kg} / \mathrm{d}(P<0.01)$, ECM by 2.8 $\mathrm{kg} / \mathrm{d}(P<0.01)$, milk fat concentration by 0.65 units $(P<0.01)$, milk fat yield by $240 \mathrm{~g} / \mathrm{d}(P<0.01)$, and ECM per DMI by 0.14 units $(P<0.01)$. However, SBO increased milk protein concentration by 0.07 units $(P$ $<0.01)$ and milk protein yield by $40 \mathrm{~g} / \mathrm{d}(P=0.04)$ compared with PAT.

\section{Body Composition}

Treatment did not alter BCS $(P=0.13)$, BCS gain $(P=0.81)$, or fat thickness over the rump $(P=0.67)$ and rib $(P=0.45)$. However, SBO increased daily BW gain by $0.27 \mathrm{~kg} / \mathrm{d}(P=0.04)$ compared with PAT.

\section{Calculated Energy Values and Partitioning}

Compared with PAT, SBO decreased milk energy output by $2 \mathrm{Mcal} / \mathrm{d}$ (Table 3) and increased energy deposited in body tissue by $1.93 \mathrm{Mcal} / \mathrm{d}(P<0.01)$. As a percentage, SBO decreased the MilkE fraction of $\mathrm{NE}_{\mathrm{L}}$ by 5 units $(P<0.01)$ and increased the BodyE fraction of $\mathrm{NE}_{\mathrm{L}}$ by 4.7 units $(P<0.01)$. Based on cow performance, apparent dietary $\mathrm{NE}_{\mathrm{L}}$ values were similar for the $2 \operatorname{diets}(P=0.51)$.

\section{Digestibility}

Compared with PAT, SBO did not alter DM digestibility $(P=0.34$; Table 4$)$, tended to reduce NDF digestibility $(P=0.09)$, and increased 16-carbon FA digestibility $(P<0.01)$. We observed treatment by period interactions for total FA digestibility and 18-carbon FA digestibility. Specifically, SBO increased total FA digestibility in period 1, with no effect in period 2; SBO decreased 18-carbon FA digestibility in period 2, with no effect in period 1.

\section{Plasma Metabolites and Hormones}

Compared with PAT, SBO increased plasma concentration of insulin by $0.16 \mu \mathrm{g} / \mathrm{L}(P=0.03)$, nonesterified fatty acids by $15 \mu \mathrm{Eq} / \mathrm{L}(P<0.01)$, and triglycerides by $0.6 \mathrm{mg} / \mathrm{dL}(P=0.05)$. We observed a treatment 
by period interaction for plasma glucose, where SBO increased plasma concentration of glucose in period 1 , but not in period 2 (Table 5).

\section{Milk Fatty Acids}

Milk FA yields and concentration are shown in Table $6(<16$ carbon FA are from de novo synthesis in the mammary glands; $>16$ carbon FA originate from extraction from plasma; 16 carbon FA are from mixed sources). Compared with PAT, SBO reduced de novo FA yield by $65 \mathrm{~g} / \mathrm{d}(P<0.01)$ and concentration by 1.4 percentage units $(P<0.01)$. The $\mathrm{SBO}$ also reduced mixed source milk FA yield by $178 \mathrm{~g} / \mathrm{d}(P<0.01)$ and concentration by 8.7 percentage units $(P<0.01)$. In contrast, SBO did not alter preformed milk FA yield $(P$ $=0.27$ ), but increased preformed FA concentration by 10 percentage units $(P<0.01)$. Compared with PAT, SBO increased yields of trans-10 C18:1 by $14.9 \mathrm{~g} / \mathrm{d}$ $(P<0.01)$ and t10c12CLA by $0.11 \mathrm{~g} / \mathrm{d}(P<0.01)$. The SBO also increased concentration of milk trans-10 C18:1 by 2.05 percentage units $(P<0.01)$ and t10c12CLA by 0.02 percentage units $(P<0.01)$. Further details regarding the yield and concentration of specific FA are shown in Supplemental Tables S1 and S2 (https: //doi.org/10.3168/jds.2019-18100).

\section{DISCUSSION}

In our previous study (Boerman et al., 2015), concentrations of both plasma insulin and milk t10c12CLA were increased in cows fed high-starch diets; thus, it was difficult to differentiate the effects of t10c12CLA and insulin on production performance and energy partitioning. We acknowledge that other mechanisms might explain the nutrient partitioning in Boerman et al. (2015); however, given that effects of insulin and t10c12CLA on nutrient partitioning are well documented in prior work (Bauman and Griinari, 2001; Harvatine et al., 2009; Bauman et al., 2011), we focused on insulin and t10c12CLA. To better understand the effect of t10c12CLA, independent of insulin, we fed cows diets containing similar starch content and supplemented with either palmitic acid-enriched triglycerides or soybean oil. With these 2 supplements, we could minimize rumen issues and promote milk fat synthesis with the diet containing palmitic acid-enriched triglycerides and cause MFD with the diet containing soybean oil. These diets caused significant differences in t10c12CLA production while causing relatively small changes in insulin secretion, which might help us distinguish the effect of t10c12CLA from that of insulin.

As seen in other MFD studies (Tyrrell and Moe, 1972; Boerman et al., 2015), SBO partitioned more energy toward body tissue gain instead of milk fat synthesis compared with PAT. In our study, milk energy output decreased $2 \mathrm{Mcal} / \mathrm{d}$, which was all from decreased milk fat output, and estimated body tissue energy gained was $2 \mathrm{Mcal} / \mathrm{d}$. This calculated body tissue energy gain was based on BW gain and was not supported by a gain in BCS or back fat thickness. We calculated BW change for each cow within treatment periods by linear

Table 6. Milk fatty acid (FA) yields and concentration of cows fed treatment diets $(\mathrm{n}=32)^{1}$

\begin{tabular}{|c|c|c|c|c|}
\hline \multirow[b]{2}{*}{ Item } & \multicolumn{2}{|c|}{ Treatment $^{2}$} & \multirow[b]{2}{*}{ SEM } & \multirow{2}{*}{$\frac{P \text {-value }}{\text { TRT }}$} \\
\hline & PAT & $\mathrm{SBO}$ & & \\
\hline \multicolumn{5}{|l|}{ FA yield, $\mathrm{g} / \mathrm{d}$} \\
\hline De novo & 292 & 227 & 11.2 & $<0.01$ \\
\hline Mixed & 493 & 315 & 14.1 & $<0.01$ \\
\hline Preformed & 479 & 499 & 17.5 & 0.27 \\
\hline trans-10 C18:1 & 26.6 & 41.5 & 4.62 & $<0.01$ \\
\hline trans-10,cis-12 C18:2 & 0.159 & 0.271 & 0.03 & $<0.01$ \\
\hline \multicolumn{5}{|l|}{ FA concentration, $\mathrm{g} / 100 \mathrm{~g}$} \\
\hline De novo & 22.3 & 20.9 & 0.43 & $<0.01$ \\
\hline Mixed & 39.2 & 30.5 & 0.67 & $<0.01$ \\
\hline Preformed & 38.5 & 48.5 & 0.88 & $<0.01$ \\
\hline trans-10 C18:1 & 2.50 & 4.55 & 0.5 & $<0.01$ \\
\hline trans-10,cis-12 C18:2 & 0.014 & 0.028 & 0.003 & $<0.01$ \\
\hline
\end{tabular}

${ }^{1}$ Samples for milk FA were collected during the last $5 \mathrm{~d}$ of each treatment period (d 24 to 28).

${ }^{2}$ Treatments contained $2.5 \%$ added palmitic acid-enriched triglyceride (PAT) or soybean oil (SBO) on a DM basis.

${ }^{3} P$-value associated with treatment differences (PAT vs. SBO; TRT).

${ }^{4}$ All $P$-values for treatment $\times$ period are $>0.50$.

${ }^{5}$ De novo $=$ milk FA $<16$ carbons in length $;$ mixed $=$ milk FA 16 carbons in length; preformed $=$ milk FA $>16$ carbons in length. 
regression after 2 rounds of removing outliers in the data. This method is more accurate than measuring $\mathrm{BW}$ at the beginning and end of each treatment period. However, a question still exists whether this BW gain was a gain of body tissue or a gain of digesta. Perhaps SBO induced cholecystokinin, decreased rumen motility, increased ruminal contents mass (Della-Fera and Baile, 1980), and consequently increased BW without altering body fat mass, as observed in a previous work supplementing UFA (Bradford et al., 2008). However, we did not observe any abrupt BW change when cows switched treatments. In addition, DMI and DM digestibility were similar for SBO and PAT. Therefore, it seems unlikely that the BW gain in SBO was caused by increased mass of digesta. The order of fat deposition in cattle is internal fat, subcutaneous fat, and then interand intramuscular fat (Allen, 1976). Thus, it may be that the increase in t10c12CLA and slight increase in insulin in our current study were sufficient to affect the deposition of internal fat, but not subcutaneous and muscular fat, and therefore not BCS. Further examination is required.

In the current study, both PAT and SBO cows had MFD, with milk fat being $3.07 \%$ in PAT cows and $2.42 \%$ in SBO cows. Reduced milk fat yield in SBO in our current study, compared with PAT, was entirely attributed to de novo FA synthesis. A reduction in de novo FA yield is typical in diet-induced MFD (Boerman et al., 2015). Baumgard et al. (2001) showed that infusion of t10c12CLA resulted in greater MFD and proportionally greater reduction in de novo FA than preformed FA. As milk fat \% was lower in SBO compared with PAT (2.42 vs. 3.07\%), the reduction of de novo FA in SBO was fully expected. In contrast to the MFD study where both high starch and high oil were used (Loor et al., 2005), we observed no change in the yield of preformed $\mathrm{FA}$ and a $14 \%$ increase in plasma insulin concentration. Blood insulin concentration is generally negatively associated with yield of milk preformed FA during MFD (Corl et al., 2006; Winkelman and Overton, 2013). Therefore, glucogenic-insulin theory likely does not explain the MFD in our current study. Whether the 14\% increase in insulin had any effect on adipose depots is not clear. Compared with PAT, SBO increased amount of absorbed FA per day and blood triglyceride concentrations. Based on intake and digestibility data, SBO cows digested and absorbed $183 \mathrm{~g} / \mathrm{d}$ more 18-carbon FA (Table 4) than PAT cows. Perhaps this increase in absorbed C18 FA prevented the normal drop of preformed milk FA normally seen during MFD.

We suggest that part, if not all, of the energy partitioning in the current study was mediated by t10c-
12CLA and insulin, considering that the effects of t10c12CLA and insulin on energy partitioning are well established. A meta-analysis by Harvatine et al. (2009) showed that milk energy output significantly decreased in cows suffering CLA-induced MFD and t10c12CLA infusion significantly increased expression of lipogenic genes in adipose tissues, which suggested that t10c12CLA favored energy flow toward body tissue gain instead of milk synthesis. Based on previous work (Vernon, 2005; Bauman et al., 2011), insulin also favors energy partitioning toward body tissue gain, by inhibition of lipolysis and stimulation of lipid synthesis in adipose tissues. Al-Trad et al. (2009) observed that glucose infusion, which likely increased insulin concentration, increased BW and back fat linearly but did not alter milk energy output. These results support our speculation that insulin could play a role in the current study in terms of energy partitioning between milk fat and adipose tissue, although the effect of insulin on milk energy output is minor compared with that of t10c12CLA. To better understand the individual roles of t10c12CLA and insulin on MFD and nutrient partitioning (Table 7), we compared results in our current study with those from Boerman et al. (2015). Boerman et al. (2015) induced MFD by feeding high starch, whereas we fed high UFA while keeping dietary starch content similar. The high-starch diet of Boerman et al. (2015) increased trans-10 C18:1 yield in milk by $44 \%$, whereas SBO in our study increased trans-10 C18:1 yield in milk by $56 \%$. However, high starch caused no change in t10c12CLA, whereas SBO increased t10c12CLA yield by $69 \%$. Along with this, high starch increased insulin concentration $33 \%$, but SBO in the current study increased insulin only $14 \%$. The $14 \%$ increase of insulin in our current study is noteworthy because insulin concentration was not expected to be different between diets containing similar starch contents, as in PAT and SBO. Perhaps, the increase of insulin in SBO was due to the increased supply of UFA in SBO. Bradford et al. (2008) demonstrated that UFA increased plasma glucagon-like peptide 1, and Shigeto et al. (2015) showed that glucagon-like peptide 1 stimulated the secretion of insulin. However, to our knowledge, no experiment directly studied this pathway; this speculation needs further examination. The increase in insulin secretion might also be induced by SBO increasing rumen production of t10c12CLA. As less energy was used for milk fat synthesis in the MFD cows, more sparing of energy would induce the secretion of insulin. However, Harvatine et al. (2009) observed that increased insulin was not induced by t10c12CLA infusions in CLA-induced MFD studies. As Harvatine et al. (2009) only infused t10c12CLA for $4 \mathrm{~d}$, perhaps 
Table 7. Comparison of results between Boerman et al. (2015) and the current study

\begin{tabular}{|c|c|c|}
\hline & $\begin{array}{l}\text { Boerman et al. } \\
\qquad(2015)^{1}\end{array}$ & Current study $^{2}$ \\
\hline Item & $\begin{array}{l}\text { HS vs. HFF } \\
(P \text {-value })\end{array}$ & $\begin{array}{l}\text { SBO vs. PAT } \\
(P \text {-value })\end{array}$ \\
\hline Insulin, $\mu \mathrm{g} / \mathrm{L}$ & $33 \%(<0.01)$ & $14 \%(0.03)$ \\
\hline trans-10 C18:1, g/d & $44 \%(<0.01)$ & $56 \%(<0.01)$ \\
\hline trans-10, cis-12 C18:2, g/d & $0 \%(0.17)^{3}$ & $69 \%(<0.01)$ \\
\hline DMI, kg/d & $2 \%(0.10)$ & $-0.4 \%(0.65)$ \\
\hline $\mathrm{NE}_{\mathrm{L}}, \mathrm{Mcal} / \mathrm{kg}$ & $0.5 \%(0.64)$ & $1 \%(0.51)$ \\
\hline Milk yield, $\mathrm{kg} / \mathrm{d}$ & $3 \%(0.02)$ & $0.9 \%(0.58)$ \\
\hline Milk fat, $\mathrm{kg} / \mathrm{d}$ & $-7 \%(<0.01)$ & $-18 \%(<0.01)$ \\
\hline De novo FA, g/d & $16 \%(<0.01)$ & $-22 \%(<0.01)$ \\
\hline Mixed FA, g/d & $-25 \%(<0.01)$ & $-36 \%(<0.01)$ \\
\hline Preformed FA, g/d & $0.5 \%(0.78)$ & $4 \%(0.27)$ \\
\hline BW gain, kg/d & $136 \%(<0.01)$ & $142 \%(0.04)$ \\
\hline BCS gain, point $/ 28 \mathrm{~d}$ & $250 \%(<0.01)$ & $9 \%(0.81)$ \\
\hline MilkE, ${ }^{4} \mathrm{Mcal} / \mathrm{d}$ & $-1 \%(0.05)$ & $-7 \%(<0.01)$ \\
\hline$\Delta \mathrm{BodyE}^{5}{ }^{5} \mathrm{Mcal} / \mathrm{d}$ & $151 \%(<0.01)$ & $138 \%(<0.01)$ \\
\hline
\end{tabular}

${ }^{1}$ Treatments were either a high fiber and fat (HFF) diet containing a $2.5 \%$ (DM basis) palmitic acid-enriched fatty acid (FA) supplement or a high-starch diet (HS) diet containing a mixture of dry ground and high-moisture corn. The results indicate the values for HS relative to those for HFF expressed as a percentage.

${ }^{2}$ Treatments were diets containing either $2.5 \%$ (DM basis) palmitic acid-enriched triglyceride (PAT) or $2.5 \%$ (DM basis) soybean oil (SBO). The results indicate the values for SBO relative to those for PAT expressed as a percentage.

${ }^{3}$ The actual value of trans-10, cis-12 C18:2 in HFF was not provided in Boerman et al. (2015).

${ }^{4}$ MilkE is net energy used for milk synthesis.

${ }^{5} \Delta$ BodyE is net energy captured in body tissue.

long-term studies with t10c12CLA-infusion are needed to examine the relationship between t10c12CLA and insulin. Despite the considerable differences in insulin and t10c12CLA responses across the 2 studies (Boerman et al., 2015, and the current study), the depression in milk fat and gain in body reserves were similar (Table 7). We suggest that t10c12CLA and insulin are both critical for the change in energy partitioning that occurs during MFD, and they can function relatively independent of each other.

In our current study, we fed $2.5 \%$ supplemental fat and observed no significant difference in DMI between PAT and SBO. These results agree with the studies of Avila et al. (2000) and Kargar et al. (2010), who found that feeding unsaturated fat at $2 \%$ of the diet did not alter DMI. In contrast, several others have shown that feeding cows with diets containing unsaturated fat depressed DMI (Pantoja et al., 1996; Harvatine and Allen, 2006; Bradford et al., 2008). Avila et al. (2000) proposed that $2 \%$ unsaturated fat would not alter the cellulolytic bacteria community and therefore not alter DMI. In support of Avila et al. (2000), we found no difference in the digestibility of DM. The NDF digest- ibility in the current study was lower than expected, perhaps because our diets had high starch content, which is known to depress NDF digestibility.

Similar to the DMI results, yields of lactose and milk were not different in our study. In contrast, Boerman et al. (2015) observed higher milk yield in a high-starch diet that caused MFD. As glucose is an important substrate for supporting the synthesis of de novo FA, depressed de novo FA synthesis in MFD should increase glucose availability for lactose synthesis, with a concomitant increase in milk yield (Boerman and Lock, 2014). However, in our current study, we did not observe an increase in milk yield. We suggest that the increased blood insulin and the small increase in available glucose from reduced de novo FA synthesis were used to support the extra protein synthesis we observed; this is consistent with previous work showing that insulin stimulated milk protein synthesis in Griinari et al. (1997) and Bionaz et al. (2012). As observed previously in the MFD studies supplementing unsaturated fat and FA (Firkins and Eastridge, 1994; Pantoja et al., 1996; Relling and Reynolds, 2007), SBO decreased milk fat yield. However, milk fat content was lower than expected, even in the PAT diet. Reasons for the low fat content in our study are not clear, but the $20 \%$ drop in milk fat from PAT to SBO was still within a reasonable range for MFD, and was less than the maximal drop proposed by Griinari and Bauman (2006). In our study, we formulated basal diets that put cows at high risk of MFD by increasing starch level to $32 \%$ and lowering NDF to $25 \%$. No health issues or metabolic disorders were detected during the study. Thus, the low milk fat percentage and milk fat yield in both treatment groups likely were the results of our high-starch, low-NDF basal diet (Griinari and Bauman, 2006). In the SBO group, milk fat content dropped to $2.4 \%$, which likely was the result of adding unsaturated fat to a high-starch, low-NDF diet.

\section{CONCLUSIONS}

Feeding diets with similar levels of fat, starch, fiber, and protein, but containing soybean oil instead of palmitic acid-enriched triglycerides, caused MFD and increased BW gain without altering milk yield. Reduced milk fat yield was due to decreased de novo FA synthesis. The diet with soybean oil also decreased ECM and $3.5 \%$ FCM but increased milk protein concentration and yield. The diet with soybean oil increased concentration and yield of trans-10 C18:1 and t10c12CLA in milk, which likely explains most of the observed MFD. The diet with soybean oil also increased plasma insulin concentration. With similar dietary starch content, the 
diet containing soybean oil partitioned 5.0 percentage units more energy toward body tissue gain and 4.7 percentage units less energy toward milk synthesis, compared with the diet containing palmitic acid-enriched triglycerides. We suggest that the significant increase of t10c12CLA, instead of insulin, resulted in the observed changes in BW gain and energy partitioning in the current study; however, this hypothesis needs to be directly examined in future studies.

\section{ACKNOWLEDGMENTS}

The authors acknowledge C. L. Preseault, J. S. Liesman, D. G. Main, J. P. Boerman, Y. Sun, L. Worden, J. Garver, K. Spaans, T. Bryant, and the staff of the Michigan State University Dairy Cattle Field Laboratory for their assistance in this experiment. This project was supported by Agriculture and Food Research Initiative Competitive Grant no. 2011-68004-30340 from the USDA National Institute of Food and Agriculture (Washington, DC). The authors have not stated any conflicts of interest.

\section{REFERENCES}

Al-Trad, B., K. Reisberg, T. Wittek, G. B. Penner, A. Alkaassem, G. Gäbel, M. Fürll, and J. R. Aschenbach. 2009. Increasing intravenous infusions of glucose improve body condition but not lactation performance in midlactation dairy cows. J. Dairy Sci. 92:56455658. https://doi.org/10.3168/jds.2009-2264.

Allen, C. E. 1976. Cellularity of adipose tissue in meat animals. Fed. Proc. 35:2302-2307.

AOAC. 1990. Official Methods of Analysis. 15th ed. Association of Official Analytical Chemists, Gaithersburg, MD.

Avila, C. D., E. J. DePeters, H. Perez-Monti, S. J. Taylor, and R. A. Zinn. 2000. Influences of saturation ratio of supplemental dietary fat on digestion and milk yield in dairy cows. J. Dairy Sci. 83:1505-1519. https://doi.org/10.3168/jds.S0022-0302(00)75023 $-5$.

Bauman, D. E., and J. M. Griinari. 2001. Regulation and nutritional manipulation of milk fat. Low-fat milk syndrome. Livest. Prod. Sci. 70:15-29. https://doi.org/10.1016/S0301-6226(01)00195-6.

Bauman, D. E., K. J. Harvatine, and A. L. Lock. 2011. Nutrigenomics, rumen-derived bioactive fatty acids, and the regulation of milk fat synthesis. Annu. Rev. Nutr. 31:299-319. https://doi.org/10.1146/ annurev.nutr.012809.104648.

Baumgard, L. H., J. K. Sangster, and D. E. Bauman. 2001. Milk fat synthesis in dairy cows is progressively reduced by increasing supplemental amounts of trans-10, cis-12 conjugated linoleic acid (CLA). J. Nutr. 131:1764-1769. https://doi.org/10.1093/jn/131.6 .1764 .

Bionaz, M., W. Hurley, and J. Loor. 2012. Milk protein synthesis in the lactating mammary gland: Insights from transcriptomics analyses. In Milk Protein. InTech. W. Hurley, ed. https://doi.org/10 $.5772 / 46054$.

Boerman, J. P., and A. L. Lock. 2014. Effect of unsaturated fatty acids and triglycerides from soybeans on milk fat synthesis and biohydrogenation intermediates in dairy cattle. J. Dairy Sci. 97:70317042. https://doi.org/10.3168/jds.2014-7966.

Boerman, J. P., S. B. Potts, M. J. VandeHaar, and A. L. Lock. 2015. Effects of partly replacing dietary starch with fiber and fat on milk production and energy partitioning. J. Dairy Sci. 98:7264-7276. https://doi.org/10.3168/jds.2015-9467.

Bradford, B. J., K. J. Harvatine, and M. S. Allen. 2008. Dietary unsaturated fatty acids increase plasma glucagon-like peptide- 1 and cholecystokinin and may decrease premeal ghrelin in lactating dairy cows1. J. Dairy Sci. 91:1443-1450. https://doi.org/10.3168/ jds.2007-0670.

Cochran, R. C., D. C. Adams, J. D. Wallace, and M. L. Galyean. 1986. Predicting digestibility of different diets with internal markers: Evaluation of four potential markers. J. Anim. Sci. 63:1476-1483. https://doi.org/10.2527/jas1986.6351476x.

Corl, B. A., S. T. Butler, W. R. Butler, and D. E. Bauman. 2006. Short Communication: Regulation of milk fat yield and fatty acid composition by insulin. J. Dairy Sci. 89:4172-4175. https://doi .org/10.3168/jds.S0022-0302(06)72462-6.

Della-Fera, M. A., and C. A. Baile. 1980. CCK-octapeptide injected in $\mathrm{CSF}$ and changes in feed intake and rumen motility. Physiol. Behav. 24:943-950. https://doi.org/10.1016/0031-9384(80)90154-7.

Firkins, J. L., and M. L. Eastridge. 1994. Assessment of the effects of iodine value on fatty acid digestibility, feed intake, and milk production. J. Dairy Sci. 77:2357-2366. https://doi.org/10.3168/ jds.S0022-0302(94)77178-2.

Goering, H. K., and P. J. Van Soest. 1970. Forage Fiber Analysis (Apparatus, Reagents, Procedures, and Some Applications). Agric. Handbook No. 379. US Department of Agriculture- Agricultural Research Service, Washington, DC.

Griinari, J. M., and D. E. Bauman. 2006. Milk fat depression: Concepts, mechanisms and management applications. Ruminant physiology digestion, metabolism and impact of nutrition on gene expression, immunology and stress. 389-409. Wageningen Academic Publ., Wageningen, the Netherlands.

Griinari, J. M., M. A. McGuire, D. A. Dwyer, D. E. Bauman, D. M. Barbano, and W. A. House. 1997. The role of insulin in the regulation of milk protein synthesis in dairy cows. J. Dairy Sci. 80:23612371. https://doi.org/10.3168/jds.S0022-0302(97)76187-3.

Harvatine, K. J., and M. S. Allen. 2006. Effects of fatty acid supplements on feed intake, and feeding and chewing behavior of lactating dairy cows. J. Dairy Sci. 89:1104-1112. https://doi.org/10 .3168/jds.S0022-0302(06)72178-6.

Harvatine, K. J., J. W. Perfield II, and D. E. Bauman. 2009. Expression of enzymes and key regulators of lipid synthesis is upregulated in adipose tissue during CLA-induced milk fat depression in dairy cows. J. Nutr. 139:849-854. https://doi.org/10.3945/jn.108 .099994

Kargar, S., M. Khorvash, G. R. Ghorbani, M. Alikhani, and W. Z. Yang. 2010. Short communication: Effects of dietary fat supplements and forage: concentrate ratio on feed intake, feeding, and chewing behavior of Holstein dairy cows. J. Dairy Sci. 93:42974301. https://doi.org/10.3168/jds.2010-3168.

Lock, A. L., C. L. Preseault, J. E. Rico, K. E. DeLand, and M. S. Allen. 2013. Feeding a C16:0-enriched fat supplement increased the yield of milk fat and improved conversion of feed to milk. J. Dairy Sci. 96:6650-6659. https://doi.org/10.3168/jds.2013-6892.

Loor, J. J., A. Ferlay, A. Ollier, M. Doreau, and Y. Chilliard. 2005. Relationship among trans and conjugated fatty acids and bovine milk fat yield due to dietary concentrate and linseed oil. J. Dairy Sci. 88:726-740. https://doi.org/10.3168/jds.S0022-0302(05)72736-3.

McClymont, G. L., and S. Vallance. 1962. Depression of blood glycerides and milk-fat synthesis by glucose infusion. Proc. Nutr. Soc. 21:41.

Mertens, D. R. 2002. Gravimetric determination of amylase-treated neutral detergent fiber in feeds with refluxing in beakers or crucibles: Collaborative study. J. AOAC Int. 85:1217-1240.

NRC. 2001. Nutrient Requirements of Dairy Cattle. 7th ed. Natl. Acad. Press, Washington, DC.

Pantoja, J., J. L. Firkins, and M. L. Eastridge. 1996. Fatty acid digestibility and lactation performance by dairy cows fed fats varying in degree of saturation. J. Dairy Sci. 79:429-437. https://doi.org/10 .3168/jds.S0022-0302(96)76382-8.

Piantoni, P., A. L. Lock, and M. S. Allen. 2013. Palmitic acid increased yields of milk and milk fat and nutrient digestibility across produc- 
tion level of lactating cows. J. Dairy Sci. 96:7143-7154. https://doi .org/10.3168/jds.2013-6680.

Relling, A. E., and C. K. Reynolds. 2007. Feeding rumen-inert fats differing in their degree of saturation decreases intake and increases plasma concentrations of gut peptides in lactating dairy cows. J. Dairy Sci. 90:1506-1515. https://doi.org/10.3168/jds.S0022 -0302(07)71636-3.

Shigeto, M., R. Ramracheya, A. I. Tarasov, C. Y. Cha, M. V. Chibalina, B. Hastoy, K. Philippaert, T. Reinbothe, N. Rorsman, A Salehi, W. R. Sones, E. Vergari, C. Weston, J. Gorelik, M. Katsura, V. O. Nikolaev, R. Vennekens, M. Zaccolo, A. Galione, P. R. V. Johnson, K. Kaku, G. Ladds, and P. Rorsman. 2015. GLP1 stimulates insulin secretion by PKC-dependent TRPM4 and TRPM5 activation. J. Clin. Invest. 125:4714-4728. https://doi .org/10.1172/JCI81975.

Tyrrell, H. F., and P. W. Moe. 1972. Net energy value for lactation of a high and low concentrate ration containing corn silage. J. Dairy Sci. 55:1106-1112. https://doi.org/10.3168/jds.S0022 $-0302(72) 85632-7$.

Tyrrell, H. F., and J. T. Reid. 1965. Prediction of the energy value of the milk. J. Dairy Sci. 48:1215-1223. https://doi.org/10.3168/jds .S0022-0302(65)88430-2.
Van Soest, P. J. 1963. Ruminant fat metabolism with particular reference to factors affecting low milk fat and feed efficiency. A review. J. Dairy Sci. 46:204-216.

Vernon, R. G. 2005. Lipid metabolism during lactation: A review of adipose tissue-liver interactions and the development of fatty liver. J. Dairy Res. 72:460-469. https://doi.org/10.1017/ S0022029905001299

Winkelman, L. A., and T. R. Overton. 2013. Long-acting insulins alter milk composition and metabolism of lactating dairy cows. J. Dairy Sci. 96:7565-7577. https://doi.org/10.3168/jds.2012-6498.

\section{ORCIDS}

E. Liu @ https://orcid.org/0000-0001-8608-9074

M. J. VandeHaar ( https://orcid.org/0000-0002-8475-3493

A. L. Lock ๑ https://orcid.org/0000-0002-9282-399X 